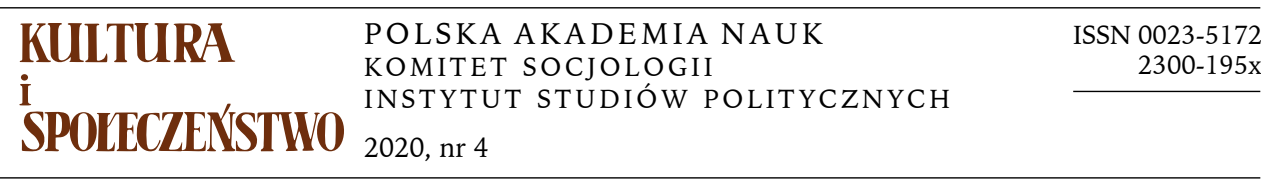
E $\quad S \quad E \quad J \quad E$
$\begin{array}{llllllllll}R & E & C & E & N & Z & Y & J & N & E\end{array}$

JAKUB NIEDBALSKI

Uniwersytet Łódzki

\title{
POZA GRANICAMI WZROKU. UWAGI NA TEMAT KSIĄŻKI KAMILA PIETROWIAKA ŚWIAT PO OMACKU*
}

Książka Kamila Pietrowiaka należy do tych opracowań, które zaskakują nadzwyczaj pozytywnie, zarówno pod względem umiejętności literackich autora, wszechstronności i głębi interpretacji, jak i z uwagi na solidny warsztat naukowo-badawczy. Jest to dzieło niezwykle oryginalne i wartościowe poznawczo, które zyskało uznanie wśród przedstawicieli różnych dyscyplin naukowych. Potwierdzeniem tego są liczne nagrody i wyróżnienia, jakimi uhonorowany został autor. Kamil Pietrowiak jest bowiem laureatem Nagrody im. prof. Elżbiety Tarkowskiej w kategorii: „autorska (współautorska) praca naukowa z zakresu nauk społecznych o problemach ubóstwa i wynikającego z niego wykluczenia społecznego", sama zaś dysertacja, na bazie której powstała monografia, znalazła uznanie jury konkursu Monografie Fundacji Nauki Polskiej, a także otrzymała nagrodę w konkursie organizowanym przez Polskie Towarzystwo Pedagogiczne na wyróżniającą się rozprawę doktorską w roku 2018 oraz I nagrodę w XVI edycji konkursu na najlepsze prace naukowe poświęcone tematyce niepełnosprawności „Otwarte Drzwi”. Nadmienić należy, iż wartość pracy

\footnotetext{
Adres do korespondencji: jakub.niedbalski@uni.lodz.pl; ORCID: 0000-0002-2803$-7628$

* Kamil Pietrowiak, Świat po omacku. Etnograficzne studium (nie)widzenia i (nie)sprawności, Wydawnictwo Naukowe UMK, Toruń, stron 516.
} 
doktorskiej już wcześniej doceniła Rada Wydziału Filozoficzno-Historycznego Uniwersytetu Łódzkiego, która — zgodnie z wnioskiem komisji doktorskiej — przyjęła uchwałę o wyróżnieniu rozprawy oraz rekomendacji jej do druku.

Książka Kamila Pietrowiaka wpisuje się w niezwykle aktualną, a zarazem wymagającą nowego spojrzenia problematykę niepełnosprawności oraz społecznego funkcjonowania osób z niepełnosprawnością. Autor nie tylko podejmuje tak ważny społecznie problem, jakim jest obecność osób niepełnosprawnych $\mathrm{w}$ różnych obszarach życia codziennego, ale też stara się spojrzeć na ów problem z niezwykle interesującej perspektywy badawczej. Swoją książkę poświęca Pietrowiak doświadczeniom, działaniom i życiowym strategiom osób niewidomych od urodzenia lub wczesnego dzieciństwa, a także ich społecznym i kulturowym uwarunkowaniom. Rozważania autora koncentrują się na specyfice funkcjonowania przedstawicieli tej grupy, przebiegu ich socjalizacji i edukacji, a także trudnościach i możliwościach w zakresie mobilności, pracy czy relacji międzyludzkich. Jest to zatem obszerne studium, w którym Pietrowiak udziela odpowiedzi na pytania dotyczące tego, $\mathrm{w}$ jaki sposób i w jakim stopniu poznawcze ograniczenia osób niewidomych, a także powszechne wyobrażenia na temat ślepoty, kształtują ich codzienne interakcje i emocje, metody radzenia sobie z życiowymi wyzwaniami oraz poczucie własnej (nie)normalności i sprawczości.

Monografia składa się z czterech zasadniczych części podzielonych na rozdziały i podrozdziały. W części pierwszej, zatytułowanej „Proces badawczy - uczestnicy, metody, zagadnienia etyczne" autor przybliża przebieg badań terenowych, kryteria doboru grupy badawczej, ogólną charakterystykę uczestników, stosowane metody oraz okoliczności gromadzenia danych, przyjęte założenia etyczne oraz ich praktyczne konsekwencje. Niewątpliwym atutem tej części monografii jest fakt, iż Pietrowiak nie ogranicza się do ogólnych stwierdzeń, wyliczeń czy deklaracji, ale przywołuje konkretne wydarzenia, wątpliwości i problemy, które pojawiały się podczas pracy terenowej i bezpośrednio wpłynęły na jej przebieg. W ten sposób pokazuje swój warsztat badacza i analityka, nie stroniąc przy tym od krytycznego spojrzenia na własną pracę. Ważnym składnikiem tej części jest również szczegółowe omówienie założeń przyjętej metody badawczej, a więc etnografii opartej na współpracy. Przy tej okazji autor prezentuje praktyczne środki realizacji badań opartych na wskazanej metodzie, a także - jak sam wskazuje - możliwości i ograniczenia tak zorientowanej praktyki badawczej.

Jednak dopiero trzy kolejne części książki wydają się kluczowe dla całego wywodu, autor prezentuje w nich bowiem wyniki swoich badań. Każda 
ze wskazanych części została poświęcona jednej z trzech zasadniczych kategorii, jakie wyłoniły się $\mathrm{w}$ trakcie prowadzonych analiz. Są to kolejno: (nie)normalność, (nie)widzialność i (nie)pełnosprawność.

W części zatytułowanej „(Nie)normalność - socjalizacja, tożsamość i wspólnota osób niewidomych" znajdujemy autorską refleksję nad tym, jaki wpływ na wczesne etapy życia oraz dalszy społeczny rozwój uczestników badań ma fakt przypisania im roli osób „nienormalnych”, a więc niespełniających przyjętych norm i standardów w zakresie zdrowia, zdolności poznawczych czy sprawności. Badacz koncentruje się na opisaniu oraz analizie najważniejszych jego zdaniem czynników, które kształtują indywidualną i grupową tożsamość osób niewidomych. Rekonstruuje przebieg kariery życiowej przedstawicieli badanej kategorii osób, począwszy od wczesnego dzieciństwa, poprzez lata nauki, po dorosłość i funkcjonowanie w ramach tworzonych przez nich związków. Wyraźnie zarysowuje się tutaj podział na trzy etapy, któremu została podporządkowana struktura tej części pracy. $\mathrm{Z}$ tego względu na plan pierwszy wysuwają się doświadczenia badanych osób $z$ okresu ich dzieciństwa, pamiętanego jako czas wypełniony silnymi emocjami, ale także nadmiernym zainteresowaniem i litością ze strony otoczenia oraz nadziejami na odzyskanie wzroku, pragnieniami powrotu do „normalnego” życia, aż po pogodzenie się i zaakceptowanie zaistniałej sytuacji. Wyraźnie zaznacza się w tym miejscu rola rodziny w całym procesie „wchodzenia w rolę” niepełnosprawnego. Co warte podkreślenia, autor z pieczołowitością oddał też zmagania, dylematy i wątpliwości członków owych rodzin, rekonstruując w ten sposób szeroki kontekst przemian tożsamościowych osób niepełnosprawnych. Istotne miejsce zajmują tu także doświadczenia większości rozmówców z ich pobytu w specjalnych ośrodkach szkolno-wychowawczych. To właśnie opis oraz analiza relacji personelu tego rodzaju ośrodków $z$ badanymi osobami w okresie ich edukacji odnosi się do drugiego etapu kariery tożsamościowej. Personel ośrodka - jak trafnie zauważa Pietrowiak - w znacznym stopniu decydował o przebiegu socjalizacji uczniów, kreując ich potrzeby, stwarzając im określone możliwości czy stawiając przeszkody i ograniczenia. Trzecim etapem kształtowania się tożsamości osób badanych jest okres dorosłości i towarzszące mu dylematy oraz problemy. W tym kontekście Pietrowiak wiele uwagi poświęca związkom uczuciowym, zwłaszcza gdy dotyczą one relacji między osobami niewidzącymi i niedowidzącymi, kontrowersjom związanym $z$ posiadaniem dzieci przez niewidome małżeństwa, a także lękom przed odrzuceniem ze strony widzących partnerów oraz roli organizacji pozarządowych w budowaniu wspólnoty osób niewidzących. 
Wyjaśnieniu badanych zjawisk i procesów służą przyjęte przez Pietrowiaka sposoby rozumienia podstawowych kwestii, pojęć i kategorii związanych — jak sam to ujmuje — „z procesem ludzkiego odnajdywania i urządzania się w świecie”. Badacz posługując się pojęciami takimi jak: kultura, socjalizacja, środowisko, język, habitus, odwołuje się do teorii Petera Bergera i Thomasa Luckmanna (2010), Pierre'a Bourdieu (2006), czy Tima Ingolda $(2003,2006)$. Omawiając zaś znaczenie czynności hierarchizacji, stereotypizacji i stygmatyzacji inspiracje czerpie z rozważań Mary Douglas (2007) oraz Ervinga Goffmana (2005, 2006, 2008, 2012). Co ważne, wskazani autorzy i ich teorie nie tylko są istotne w kontekście pierwszej części, ale także systematycznie rozwijane i precyzowane w toku dalszych rozważań.

Koleja część książki, zatytułowana „(Nie)widzialność — osoby niewidome wobec norm, wartości i reguł kultury wizualnej" — została poświęcona przedstawieniu wpływu ślepoty na wybrane wymiary życia uczestników badań, w tym między innymi na ich rozumienie zjawisk wizualnych, stosowane środki komunikacji, przebieg codziennych interakcji czy sposoby zarządzania własnym ciałem oraz wizerunkiem. Autor prezentuje tutaj potoczne oraz naukowe założenia dotyczące ślepoty, które wynikają bezpośrednio $z$ wartości i funkcji przypisanych poznaniu wizualnemu. Sporo miejsca poświęca wyjaśnieniu tego, w jaki sposób badane osoby wyobrażają sobie możliwości poznawcze „widzących” oraz poszczególne elementy widzialności, a więc barwy, perspektywę, wygląd ludzi i obiektów. Punktem wyjścia do rozważań na temat tak zarysowanych „praktyk wizualnych" osób niewidomych Pietrowiak uczynił odwołania do dzieł Williama Mitchella (2013), Nicholasa Mirzoeffa $(1999,2016)$ oraz Hala Fostera (1988). Czerpiąc inspirację $z$ ich prac, skoncentrował się na znaczeniu zmysłu wzroku dla rozwoju oraz funkcjonowania człowieka — zarówno na poziomie gatunkowym, grupowym, jak i jednostkowym - a także na jego dominującej roli w hierarchii percepcji wypracowanej w cywilizacji zachodniej. W tej części znalazły się także zagadnienia odnoszące się do analizy procesu, w toku którego uczestnicy badań stopniowo odkrywają prawidłowości zachodzące w obrębie widzialnego świata, przyswajają pojęcia i zwroty językowe odnoszące się bezpośrednio do poznania wizualnego, a także stykają się z różnego rodzaju obrazami i przedstawieniami, które stanowią podstawowe nośniki informacji i emocji. Autor przedstawia również sposoby i okoliczności, w jakich osoby niepełnosprawne wcielają podstawowe „wizualne obowiązki” odnoszące się do sfery wizerunku, ekspresji czy komunikacji pozawerbalnej, jak zarządzają widzialnością własnego „piętna”, a także jakie podejmują 
działania w celu budowania własnej tożsamości, atrakcyjności czy seksualności.

W czwartej, a zarazem ostatniej części książki, „(Nie)pełnosprawność - wymiary sprawczości i niezależności osób niewidomych", zostają ukazane materialne, społeczne oraz instytucjonalne możliwości i ograniczenia uczestników badań, które mają istotny wpływ na stopień oraz zakres ich sprawności, samodzielności i zaradności. W związku z tym Pietrowiak omawia podstawowe elementy publicznego systemu wsparcia osób niepełnosprawnych w Polsce, a także ich faktyczny wpływ na życiowe decyzje i taktyki bohaterów jego rozprawy. Następnie opisuje przebieg procesu rehabilitacji poszczególnych rozmówców, w założeniu mającego na celu zwiększenie zakresu ich sprawczości. Jak zauważa, proces ten jest kontrolowany i oceniany przez przedstawicieli odpowiednich instytucji, w tym pracowników ośrodków szkolno-wychowawczych. Istotnym wątkiem w problematyce samodzielności i sprawności osób niewidomych są również kwestie związane $\mathrm{z}$ ich zatrudnieniem, czyli specyfika możliwości zawodowych, dostępne oferty pracy, publiczne formy wsparcia czy motywacje niepełnosprawnych pracowników oraz ich pracodawców. Badacz koncentruje się również na umiejętnościach i ograniczeniach osób niewidomych w dziedzinie samodzielnej mobilności i orientacji przestrzennej. W tym kontekście zwraca uwagę na liczne trudności wynikające $z$ braku lub głębokiego uszkodzenia zmysłu wzroku i przechodzi do konkretnych narzędzi i sposobów samodzielnego radzenia sobie w pozadomowej przestrzeni - podstawowych zdolności orientacyjnych, technik posługiwania się białą laską, współpracy z psami asystującymi. Na zakończenie Pietrowiak porusza kwestie korzystania z pomocy widzących przewodników i asystentów, a także związane $z$ tym emocje, potrzeby i dylematy zgłaszane przez uczestników badań. Wspomnieć również należy o bogactwie odwołań do literatury przedmiotu, $z$ jaką mamy do czynienia $\mathrm{w}$ tej części książki. Swoje inspiracje teoretyczne autor czerpie między innymi z prac Margaret Archer (2013a, 2013b), Herberta Blumera (2007) czy Alfreda Schütza (1984, 2008), a także Anthony'ego Giddensa (2003, 2004), poszukując $w$ nich poparcia dla swoich analiz dotyczących zasadniczych uwarunkowań działania ludzkiego, w tym indywidualnej sprawczości. Nie poprzestaje jednak na tym i sięga również do teorii wyjaśniających zjawisko upośledzenia oraz niepełnosprawności (ślepoty) zarówno w wymiarze fizycznym, społecznym, jak i kulturowym.

W podsumowaniu autor przedstawia w sposób kompleksowy, szczegółowy i przejrzysty wnioski z badań, wyjaśniając mechanizmy oraz procesy badanego zjawiska. Warto podkreślić, że w zakończaniu nie stroni od au- 
tokrytyki i ukazania ewentualnych luk w swojej pracy, przez co nie tylko zyskuje ona na wiarygodności, ale także staje się doskonałą bazą dla dalszych badań w eksplorowanym obszarze niepełnosprawności.

Książka Kamila Pietrowiaka ma kilka niewątpliwych zalet, które wyróżniają ją na tle polskich badań naukowych dotyczących niepełnosprawności wzrokowej.

Po pierwsze, została oparta na sześcioletnich badaniach etnograficznych z udziałem osób niewidzących. Autor zastosował różnego rodzaju metody jakościowe - w tym między innymi wywiady narracyjne, obserwację uczestniczącą i nieuczestniczącą — które pozwoliły mu na uzyskanie bogatych i różnorodnych danych na temat opisywanej grupy. Podstawowymi uczestnikami badań były 22 osoby niewidzące, $z$ którymi autor odbył ok. 450 spotkań. Oprócz tego przeprowadził on wiele rozmów i obserwacji w ogólnie rozumianym środowisku osób niewidomych, na które składają się także osoby niedowidzące, widzący członkowie rodzin i znajomi, przedstawiciele instytucji i organizacji wspierających osoby niepełnosprawne. Zebrane $\mathrm{w}$ ten sposób informacje, wypowiedzi i obserwacje zostały czytelnie przedstawione i uporządkowane. Co niezwykle istotne, autor nie traktował tych danych w sposób przedmiotowy — nie próbował za ich pomocą potwierdzić lub sfalsyfikować obranych z góry teorii na temat ślepoty lub niepełnosprawności. Proces badawczy polegał na stopniowym „wyłanianiu się" kolejnych wątków i zagadnień, a także regularnym zestawianiu materiału empirycznego $z$ dociekaniami wybranych tyflopedagogów, antropologów, socjologów i filozofów. W ten sposób otrzymujemy wiarygodną i wyważoną opowieść o życiu osób niewidzących, która nie sprowadza się ani do „suchego" opisu przedmiotu i podmiotów badań, ani do pochopnych generalizacji i teorii budowanych w oderwaniu od codziennych doświadczeń bohaterów rozprawy.

Po drugie, innowacyjne jest zastosowane przez Pietrowiaka podejście badawcze, które stanowi realizację postulatów etnografii opartej na współpracy (collaborative ethnography). Zgodnie $z$ nimi uczestnicy badań powinni zostać włączeni, a przynajmniej zaproszeni do aktywnego udziału w całym procesie badawczym - od ustalania pytań badawczych, poprzez weryfikację kolejnych wniosków, aż po ocenę ostatecznego raportu $z$ badań. Kamil Pietrowiak zastosował te rozwiązania na każdym etapie realizowania swojej pracy oraz włączył do książki komentarze uczestników badań, które odnoszą się bezpośrednio do jej poszczególnych części. W moim przekonaniu oprócz walorów poznawczych czy metodologicznych taki zabieg ma wyraźną wartość etyczną i integracyjną. Faktyczne oddanie głosu osobom niepełnosprawnym jest wyrazem sprzeciwu autora wobec sytuacji - nie- 
rzadkiej w badaniach na temat tej grupy - w której są one stawiane w roli „przedmiotów” badań czy „królików doświadczalnych” (cytat z wypowiedzi jednego $z$ bohaterów książki).

Po trzecie, za wartościową uznaję otwartość autora wobec tematyki ślepoty i niepełnosprawności. Kamil Pietrowiak nie rozpoczynał badań z gotowymi tezami czy oczekiwaniami, lecz stopniowo zagłębiał się $\mathrm{w}$ wybraną problematykę, korzystając przy tym $\mathrm{z}$ wielu dostępnych źródeł wiedzy naukowej i popularnonaukowej. W związku z tym otrzymujemy pracę prawdziwie interdyscyplinarną, czerpiącą z dokonań tyflopedagogów i tyflopsychologów, badaczy z kręgu disability studies, antropologów, socjologów i filozofów. Jednocześnie - co warto podkreślić - autor nie odnosi się bezrefleksyjnie i bezkrytycznie do omawianych teorii i badań, lecz konfrontuje je $z$ zebranym materiałem empirycznym. W tym sensie książka $z$ jednej strony zawiera rzetelne odniesienia do badań polskich przedstawicieli pedagogiki specjalnej — w tym między innymi Marii Grzegorzewskiej $(1964,1968)$, Tadeusza Majewskiego (1973, 1983, 1996), Zofii Palak (2000) i Hanny Żuraw (2008); z drugiej natomiast ukazuje korzyści płynące $z$ poszerzania perspektywy badań nad niepełnosprawnością, które $z$ powodzeniem mogą inspirować się dokonaniami innych dyscyplin humanistycznych i społecznych.

Po czwarte wreszcie, autor porusza wiele zagadnień dotyczących funkcjonowania osób niewidzących w systemie edukacji specjalnej i pomocy społecznej. Kamil Pietrowiak szczegółowo opisuje strategie, praktyki i emocje uczestników badań związane $z$ długoletnim pobytem $\mathrm{w}$ szkolno-wychowawczych ośrodkach specjalnych, poszukiwaniem pracy czy procesem rehabilitacji, w tym nauką orientacji przestrzennej. Te wyniki badań z pewnością zainteresują przedstawicieli instytucji i organizacji związanych $z$ edukacją i rehabilitacją osób niewidomych, w tym przede wszystkim wychowawców w ośrodkach specjalnych, asystentów zawodowych oraz instruktorów orientacji przestrzennej. Dodatkowo autor omawia wiele problematycznych, a często również bolesnych i budzących poczucie niesprawiedliwości kwestii, które — jak sądzę - wymagają odpowiedniego przepracowania w szeroko pojętym środowisku osób niewidomych.

Monografia Kamila Pietrowiaka wyróżnia się wysokim poziomem merytorycznym oraz oryginalnością ujęcia przedmiotu badań. Jest to praca wyjątkowa na gruncie polskich badań nad niepełnosprawnością. Stanowi niezwykle użyteczne kompendium wiedzy, łącząc badawczą otwartość, rzetelność i uczciwość. Przekraczaa utarte podziały między dyscyplinami. Napisana przystępnym językiem, nie zawiera jednak łatwych odpowiedzi i sentymentalnych deklaracji. Jako taka z pewnością zainteresuje zarówno 
pedagogów specjalnych, tyflopedagogów, antropologów i socjologów w tym studentów tych kierunków — jak i czytelników pozaakademickich.

\section{BIBLIOGRAFIA}

Archer Margaret S., 2013a, Człowieczeństwo. Problem sprawstwa, tłum. Agata Dziuban, Nomos, Kraków.

Archer Margaret S., 2013b, Jak porzadek społeczny wpływa na ludzkie sprawstwo? Refleksyjność jako mechanizm pośredniczacy między struktura a sprawstwem, tłum. T. Skoczylas, w: Adam Mrozowicki, Olga Nowaczyk, Irena Szlachcicowa (red.), Sprawstwo. Teorie, metody, badania empiryczne w naukach społecznych, Nomos, Kraków, s. 19-35.

Berger Peter L., Luckmann Thomas, 2010, Społeczne tworzenie rzeczywistości. Traktat z teorii wie$d z y$, tłum. Józef Niżnik, Wydawnictwo Naukowe PWN, Warszawa.

Blumer Herbert, 2007, Interakcjonizm symboliczny. Perspektywa i metoda, tłum. Grażyna Woroniecka, Nomos, Kraków.

Bourdieu Pierre, 2006, Dystynkcje: klasy i klasyfikacje, tłum. Piotr Biłos, w: Aleksandra Jasińska-Kania, Lech M. Nijakowski, Jerzy Szacki, Marek Ziółkowski (oprac.), Współczesne teorie socjologiczne, t. 2, Scholar, Warszawa, s. 634-650.

Douglas Mary, 2007, Czystość i zmaza, tłum. Marta Bucholc, Państwowy Instytut Wydawniczy, Warszawa.

Foster Hal, 1988, Preface, w: Hal Foster (red.), Vision and Visuality, Bay Press, Seattle, s. IX-XIV.

Giddens Anthony, 2003, Stanowienie społeczeństwa: zarys teorii strukturacji, tłum. Stefan Amsterdamski, Zysk i S-ka, Poznań.

Giddens Anthony, 2004, Socjologia, tłum. Alina Szulżycka, Wydawnictwo Naukowe PWN, Warszawa.

Goffman Erving, 2005, Piętno. Rozważania o zranionej tożsamości, tłum. Aleksandra Dzierżyńska, Joanna Tokarska-Bakir, Gdańskie Wydawnictwo Psychologiczne, Gdańsk.

Goffman Erving, 2006, Charakterystyka instytucji totalnych, tłum. Z. Zwoliński, w: Aleksandra Jasińska-Kania, Lech M. Nijakowski, Jerzy Szacki, Marek Ziółkowski (oprac.), Współczesne teorie socjologiczne, t. 1 Scholar, Warszawa, s. 317-335.

Goffman Erving, 2008, Człowiek w teatrze życia codziennego, tłum. Helena Datner-Śpiewak, Paweł Śpiewak, Aletheia, Warszawa.

Goffman Erving, 2012, Rytuat interakcyjny, tłum. Alina Szulżycka, Wydawnictwo Naukowe PWN, Warszawa.

Grzegorzewska Maria, 1964, Wybór pism, Państwowe Wydawnictwo Naukowe, Warszawa.

Grzegorzewska Maria, 1968, Pedagogika specjalna, skrypt wykładów, Warszawa.

Ingold Timothy, 2003, Kultura i postrzeganie środowiska, tłum. G. Pożarlik, w: Marian Kempny, Ewa Nowicka (red.), Badanie kultury. Elementy teorii antropologicznej, Wydawnictwo Naukowe PWN, Warszawa, s. 73-86.

Ingold Timothy, 2009, Ewoluujące umiejętności, tłum. Magdalena Polaszewska-Nicke, w: Andrzej Klawiter (red.), Formy aktywności umystu. Ujęcia kognitywistyczne, t. 2: Ewolucja i złożone struktury poznawcze, Wydawnictwo Naukowe PWN, Warszawa, s. 110-131.

Majewski Tadeusz, 1973, Niewidomi wśród widzących, Państwowy Zakład Wydawnictw Lekarskich, Warszawa. 
Majewski Tadeusz, 1983, Psychologia niewidomych i niedowidzacych, Państwowe Wydawnictwo Naukowe, Warszawa.

Majewski Tadeusz, 1996, Poglady i działalność Krajowej Federacji Niewidomych w Stanach Zjednoczonych, „Zeszyty Tyflologiczne”, nr 14, Polski Związek Niewidomych, Warszawa.

Mirzoeff Nicholas, 1999, An Introduction to Visual Culture, Routledge, London-New York.

Mirzoeff Nicholas, 2016, Jak zobaczyć świat, tłum. Łukasz Zaremba, Karakter-Muzeum Sztuki Nowoczesnej, Kraków-Warszawa.

Mitchell W. J. T., 2013, Czego chca obrazy?, tłum. Łukasz Zaremba, Narodowe Centrum Kultury, Warszawa.

Palak Zofia, 2000, Uczniowie niewidomi i słabowidzacy w szkołach ogólnodostępnych, Wydawnictwo UMCS, Lublin.

Schütz Alfred, 1984, Potoczna i naukowa interpretacja ludzkiego dziatania, tłum. Dorota Lachowska, w: Edmund Mokrzycki (red.), Kryzys i schizma. Antyscjentyczne tendencje w socjologii wspótczesnej, t. 1, Państwowy Instytut Wydawniczy, Warszawa, s. 137-192.

Schütz Alfred, 2008, O wielości światów. Szkice z socjologii fenomenologicznej, tłum. Barbara Jabłońska, NOMOS, Kraków.

Żuraw Hanna, 2008, Udział osób niepetnosprawnych w życiu społecznym, Wydawnictwo Akademickie Żak, Warszawa.

\title{
BEYOND THE BOUNDS OF SIGHT: REMARKS ON KAMIL PIETROWIAK'S BOOK ŚWIAT PO OMACKU
}

\author{
Jakub Niedbalski \\ (University of Lodz)
}

\section{Abstract}

The aim of the essay is to discuss Kamil Pietrowiak's work Świat po omacku. Etnograficzne studium (nie) widzenia i (nie)sprawności (2019) [The World by Feel: An Ethnographic Study of (Not) Seeing and (Dis)Ability]. In his book, Pietrowiak introduces and explains the cognitive limitations of blind people and social perceptions of blindness itself, which shape everyday life for people in this group. Pietrowiak's analyses and reflections are based on the results of ethnographic research (collaborative ethnography) conducted among the blind, their family members and friends, and the employees of institutions and organizations working on their behalf. The author of the essay believes that Pietrowiak's approach is innovative and that he has made a valuable contribution to the subject, especially in consideration of the general level of scholarly and popular knowledge of disabilities.

key words: disability, blind people, collaborative ethnography

stowa kluczowe: niepełnosprawność, osoby niewidome, etnografia oparta na współpracy 